\title{
THE SUPERVISION OF MULTICULTURAL BASED LEARNING ON EARLY CHILDHOOD EDUCATIONAL INSTITUTIONS
}

\author{
Ahmad Samawi \\ Teacher Education of Early Childhood Education, Faculty of Education, \\ State University of Malang, Indonesia \\ ahmad_samawi61@yahoo.com
}

\begin{abstract}
This study aimed to describe the supervision of multicultural based learning on educational institutions early childhood. This research used descriptive research design. The population was all teachers of kindergarten / PAUD in the city of Malang. The research sample as much as $20 \%$ taken area random stratified sampling. The instrument used was a questionnaire and interview guides and documentation. The analysis technique used is percentage descriptive analysis. The results showed that: (1) the vast majority of early childhood teachers in Malang were collaborative supervision; (2) the success factors of Early Childhood Education teacher in city of Malang were supervision benefit, cooperative attitude of the teachers, rules system that is applied in the school and neighborhood, and school condition; (3) the obstacle factors of Early Childhood Education teacher were too much work, the distance of the school, less conducive school condition, the attitude and thoughts of the teachers that less adaptive to innovations, time and schedule that out of supervision; and (4) the efforts of the school to overcome the obstacle of the supervision are make use of meeting forum of Head of School working group of HIMPAUDI or IGTKI, human resources development, and by internal, external and interactive strategy. It is concluded that coaching pattern of early childhood education teacher in city of Malang is collaborative coaching. It is suggested that the supervisors shall do the coaching in accordance with the collaborative pattern of coaching.
\end{abstract}

Keywords: early childhood education, multicultural

\section{INTRODUCTION}

The experts, teachers, society, and government become more aware that early childhood education (Pendidikan Anak Usia Dini - PAUD) is really important to the development of the nation. The success of PAUD is not only determine the success of education of the child on next stage, but also determine the increase of quality of the human resources. The success even gives bonus of the demographic of good human resources in the future [6], [10]. Multicultural education on late $20^{\text {th }}$ century to early $21^{\text {st }}$ makes society become more aware that the flow of information and communication gives transparent effect on the society itself. Recently, the society become more susceptible to the existence of another society that is different in all aspects.

They should be able to live together in peace on the interaction, responsibility and rights, and in respecting each other. Nowadays, there is no society that is higher than another, but they cooperate and depend each other. This diversity in society really influence the teacher performance and the quality of the education. The society become more aware of the quality that is given by the teacher to their student.

The factor that affects the success of PAUD is really complex, for example children growth, nutritional, teacher's family, society, or government. The teacher often not fully understands the growth of the children, which makes the education level is beyond the children abilities. The atmosphere of the education that is safe and comfortable by playing activities also not fully conducted by the teacher. The economics condition and education level of the parents also affect the quality of the nutrition which affect the children growth. The society understanding of PAUD will gives appreciation and support to PAUD institutions. The welfare of PAUD teacher is still low by the perception of the society that PAUD is a nonprofit institution [7].
Another research Ekosusilo \& Soepardjo [4] shows that the factor of organizational culture gives the biggest affect to the teacher's job satisfaction level compared to performance, motivation, pedagogic competence and the leadership of the head of the school. The teachers have not yet successfully in developing the children ability in learning. This shown on teacher response on children behavior during learning process. The teacher conception on emotional stability and faith will affect the teacher's act in interaction with the children, Adi Atmoko [5]. They need assistance from the supervisor of education, whose need to pay attention to the multicultural aspect in PAUD institution. The supervisor activity in assist the teacher in solving the learning problem is called supervision.

According to Segiovanni (1982), the factor that affect the supervision activity is education goal, authority, can be socially implemented to reach that education goal [9]. Interaction between supervisor and PAUD teacher is determined by multicultural factor that exist in the PAUD institution. The supervisor is unlikely to work alone in assist the teacher, but also need to cooperate with the head of school, regional government, family and society. This is because PAUD institution has diversity in culture. This cultural diversity aspect give huge effect to the learning activity in PAUD institution.

\section{METHODS}

This research implements the research design of descriptive percentage. The research population is all kindergarten in Malang city. The respondent is kindergarten supervisor, head of school, and teacher. The sample is set to $20 \%$ by stratified random sampling. The sample determination based on geographical area of Malang city which consist of 5 districts: Lowokwaru, Klojen, Kasin, Blimbing, and Kedungkandang. The population density is different 
between 5 districts therefore the amount of respondents in each district is different. The instrument that is used is Questionnaire, guided interview and documentation.

\section{RESULT AND DISCUSSION \\ 1. Multicultural Supervision Model}

Culture is human identity that differs it from another creature. As identity, culture covers all human life, such as idea, behavior, and the product that is obtained from learning as the member of society. As cultural institution, PAUD is a multicultural educational institution for early children. PAUD has its own multicultural institution that have its unique identity that is different with another multicultural institution. It is different because PAUD has speciality to introduce the cultural aspect to early children safely and comfortably thus they can be the member of the society in the future.

The implementation of multicultural based supervision was mainly $(65 \%)$ conducted by face to face and class observation (35\%). The face to face activity and observation will encourage the emotional relation of professional partnership between supervisor and teacher in solving learning problem. The only technique that was used in multicultural supervision is individual technique $(86 \%)$. This technique ensure the secrecy of the teacher advantages and disadvantages, thus mutual trust is gained between both parties. The communication language that was used orally or written is standard and formal Bahasa Indonesia. The use of standard Bahasa Indonesia unsure the same understanding from different cultural perspective, local or foreign culture.

Most of the PAUD teacher $(78 \%)$ in Malang city prefer collaborative learning supervision model. By this collaborative model, PAUD teacher and supervisor could reflect to find the desired needs and values by different society, Blass, Jasman, and Levy [3]. Together, the teachers and supervisors could determine the learning program that accommodate the different society to be presented to the children in the class. According to Sonhadji [11] multicultural learning model follows seven steps: multicultural neighborhood, multicultural neighborhood profile, development aspect identification, the formulation of multicultural learning theme, implementation of multicultural learning in the class, evaluation and reflection.

\section{Success and Obstacle Factors in the Learning Supervision}

Most of the success of multicultural based supervision (93\%) was very depend on cooperative behavior of teacher, school condition, and school culture. The teacher attitude that accept the critics from the supervisor will increase their capacity in learning activities. This corresponds to Kate and Bouchard (5) that the development of teacher's capacity will affect children education. Saputra (8) also found that good supervision will improve teacher's performance. The multicultural supervision changed the school quality culture, especially in give service to the children, administration, and development of human resources.
Arifin [1] found that school quality culture can be implemented by empowerment of the school, especially human resources development, mentally or professionally.

The obstacle in the learning supervision in PAUD was the vast region area and the amount of PAUD institution that is in the authority of the supervisor. The vast area aspect became one of the obstacle beside the huge work load, thus not every school can be reached. Another obstacle is the development of multicultural based learning, especially related to the implementation of 2013 curriculum. The obstacle of the implementation of the 2013 curriculum is not synchronized with school readiness, in facilities, teacher competency and the supervisor itself. This is because not all teacher had chance to attend the training of implementation of the 2013 curriculum.

\section{The Effort to overcome the learning problem}

Various effort had been conducted to overcome the problem in multicultural based learning. The effort is giving motivation and inspiration (68\%), adjusted with school culture and religious values. PAUD teachers as adult is more comfortable in learning by action rather than being lectured. Motivation and inspiration as universal part of culture formed as idea or thought is suitable for developing the school culture. Religious factor as internal power of the teachers in conducting their professional duty must be understood by the supervisor. The learning is not only a professional act but also a religious act. The vast region area and the amount of teacher to be supervised problems were overcame by act of IGTKI or HIMPAUDI. The supervisor cooperate with the two institutions conducted learning innovation that is developed, especially the implementation of the 2013 curriculum policy and its learning model.

Another effort that was conducted by supervisor is by routine supervision on the school that is reached by transportation. It was conducted in shift. That routine supervision was planned, coordinated by concerned parties, implemented and evaluated by supervisor or local educational authority institution. The head of schools role are important in developing school that the supervisor needs to cooperate with them. That cooperation is strategic since the head of school leadership influences the development of teacher's competency. This is supported by research conducted by Wiyono [12], which states that transformational leadership has strong effect in motivation and teacher's duty in learning activities.

\section{CONCLUSION}

According to analysis and discussion, it can be concluded that multicultural based learning supervision had been conducted in PAUD institution of Malang city. That supervision was conducted by collaborative approach that put the teacher as supervisor's partner in solving learning problems. Interaction and communication with the teacher using standard and formal Bahasa Indonesia to overcome the diversity in local culture. The supervision activities was conducted 
by visitation to class and observation and interview individually in comfortable atmosphere.

The success of multicultural based learning supervision was affected by cooperative attitude of the teacher, school condition, and school culture. The presence of the supervisor is needed routinely to assist in solving learning problem. The supervisor needs to pay attention to cultural aspect in school and neighborhood society thus learning improvement in the school has fully support from entire school member.

The obstacle that were found by the supervisor in multicultural based professional duty is school distance that is far because of vast area of region. Also, heavy work load of the supervisor become another problem, thus not all school can be supervised. Another important factor is cultural aspect and mental behavior of the teacher and supervisor. To overcome the obstacles, supervisor conducted a well-planned act cooperating with IGTKI and HIMPAUDI. Internship cooperation was conducted by supervisor and head of school, because head of school is the policy maker of the learning that will be implemented by the teachers.

\section{REFERENCES}

[1] Arifin, I. 2013. Kepemimpinan Kepala Madrasah dalam Meningkatkan Budaya Mutu. Ilmu Pendidikan, Jurnal Kajian Teori dan Praktik Kependidikan, 40(2): 111-117.Kemenkoinfo. 2014. Siapa Маи Bonus? Peluang Demografi Indonesia. Jakarta: Kemenkoinfo.

[2] Atmoko, A. 2012. Model Tindakan Guru Menanggapi Perilaku Siswa dalam Pembelajaran. Jurnal Ilmu Pendidikan, 17(4): 255-264.
[3] Blass, E., Jasman, A., and Levy, R. 2011. Supervisor reflections on Developing Doctoralness in PracticeBased Doctoral Students. Quality Assurance in Education, 20(1): 31-41.

[4] Ekosusilo, M., and Soepardjo. 2014. Faktor Dominan yang Mempengaruhi Motivasi Kerja, Kinerja, dan Kepuasan Kerja Guru SMA. Jurnal Ilmu Pendidikan, 20(2): 134-143.

[5] Kate, B. M., and Bouchard, K. 2011. The Capacity to Build Organizational Capacity in Schools. Journal of Rducational Administration, 49(6): 653-667.

[6] Kemenkoinfo. 2014. Siapa Mau Bonus? Peluang Demografi Indonesia. Jakarta: Kemenkoinfo.

[7] Samawi, A. 2016. Keberadaan Lembaga PAUD sebagai Lembaga Nonprofit. Proceeding Konvensi Nasional Pendidikan Indonesia, State University of Jakarta, p. 1688-1698.

[8] Saputra, Y. M. 2011. Supervisi Pembelajaran Untuk Meningkatkan Kinerja Guru Pendidikan Jasmani. Jurnal Ilmu Pendidikan, 17(5): 13-20.

[9] Sergiovanni, T. J. 1982. Supervision of Teaching. New York: ASCD.

[10] Setyawati, R. 2016. Pendidikan Wirausaha dan Keuangan sejak Dini dalam Menghadapi Bonus Demografi Indonesia. Proceeding Konvensi Nasional Pendidikan Indonesia, State University of Jakarta, p. $1655-1660$

[11] Sonhadji, A. 2012. Manusia, Teknologi, dan Pendidikan Menuju Peradaban Baru. Malang: Universitas Negeri Malang.

[12] Wiyono, B. B. 2016. The Effectiveness of Implementation of Principals Transformational Leadership in Motivating Teachers to Carry Out Their Profession Duties. Singapore Conferences. 